\title{
Contributions to the morphology and phylogeny of the newly discovered bat tick species, Ixodes ariadnae in comparison with I. vespertilionis and l. simplex
}

Sándor Hornok ${ }^{1 *}$, Jenő Kontschán ${ }^{2,3}$, Agustín Estrada-Peña ${ }^{4}$, Isabel G Fernández de Mera ${ }^{5}$, Snežana Tomanović ${ }^{6}$ and José de la Fuente ${ }^{5,7}$

\begin{abstract}
Background: Recently a new hard tick species, Ixodes ariadnae has been discovered, adding to the two known ixodid tick species (I. vespertilionis and I. simplex) of bats in Europe.

Findings: Scanning electron microscopic comparison of adult females of these species shows morphological differences concerning the palps, the scutum, the Haller's organ, the coxae, as well as the arrangement and fine structure of setae. Molecular analysis of 10 geographically different isolates revealed 90-95\% sequence homology in the $12 S$ and $16 \mathrm{~S}$ rDNA genes of bat tick species. Based on $12 \mathrm{~S}$ rDNA sequences, genotypes of $I$. ariadnae clustered closest to I. simplex, whereas according to their $16 \mathrm{~S}$ rDNA gene they were closest to I. vespertilionis. The subolesin gene of I. ariadnae had only $91 \%$ sequence homology with that of I. ricinus, and is the longest known among hard tick species.

Conclusions: The present study illustrates the morphology and clarifies the phylogenetic relationships of the three known bat tick species that occur in Europe. According to its subolesin gene I. ariadnae may have a long evolutionary history.
\end{abstract}

Keywords: Ixodes, Tick, Bat, 125 rDNA, 165 rDNA, Subolesin

\section{Findings}

\section{Background}

In Europe and in the majority of the Old World, for more than a century two ixodid ticks were known to be highly specialized to bats, i.e. the bat tick (Ixodes simplex) and the long-legged bat tick (Ixodes vespertilionis) [1]. Recently, however, a new tick species has been discovered to parasitize chiropterans, hitherto reported only from Hungary [2]. The significance of bat ticks is increased by the fact that bats frequently live close to (or in) human dwellings, and at least $I$. vespertilionis may feed on humans [3] and has been reported to be a potential vector of zoonotic bartonellae [4].

\footnotetext{
* Correspondence: hornok.sandor@aotk.szie.hu

${ }^{1}$ Department of Parasitology and Zoology, Faculty of Veterinary Science, Szent István University, Budapest, Hungary

Full list of author information is available at the end of the article
}

In the description of I. ariadnae [2] it was pointed out that it shares features with both $I$. vespertilionis (e.g. its relatively large size and long legs) and I. simplex (e.g. its short, broad palps). However, it was beyond the scope of the latter study to illustrate these similarities and differences with appropriate scanning micrographs of all three bat tick species. In addition, although the most important gene that is used for barcoding (species identification) among ticks [5], i.e. the cytochrome oxidase subunit I (COI) gene of I. ariadnae was shown to differ considerably from those of $I$. vespertilionis and I. simplex [2], examination of the taxonomic relationship of closely related species should optimally include analysis of multiple genes. Therefore it was decided to extend the previous results by a simultaneous morphological comparison of all three bat 


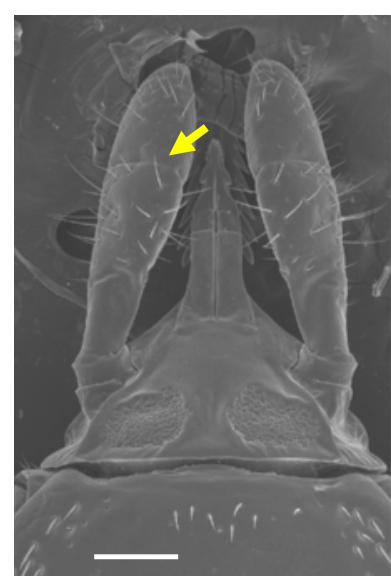

Ixodes vespertilionis

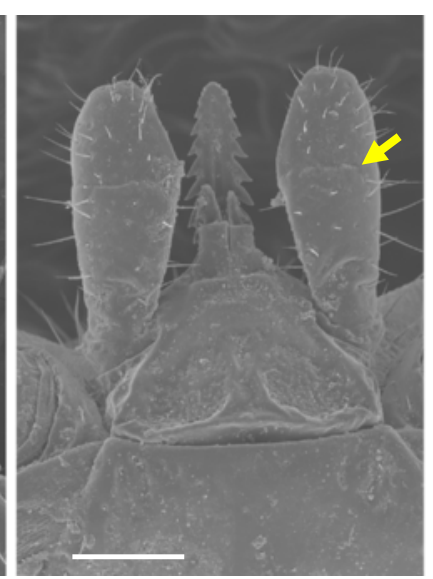

Ixodes ariadnae

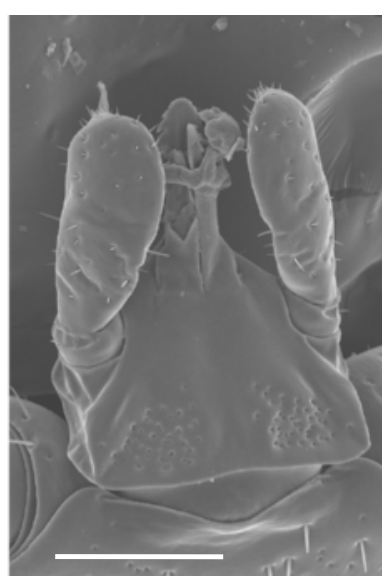

Ixodes simplex

Figure 1 Dorsal view of the gnathosoma of the three bat tick species. Arrows indicate separation of II.-III. palpal segments (bars: $200 \mu \mathrm{m})$.

tick species, together with the molecular analysis of three further (12S/16S rDNA and subolesin) genes.

\section{Methods}

The morphology of two adult females of each of the three bat tick species was compared: Ixodes vespertilionis and I. ariadnae were collected in Hungary; I. simplex was collected in Serbia. For scanning electron microscopy (performed as in [2]) females were chosen, because (a) larvae and nymphs of all three species were not available, and (b) in the adult form females are parasitic: males either do not suck blood (I. vespertilionis) or are unknown (I. ariadnae) [2].

Total nucleic acid (TNA) was extracted as described [6]. Ten TNA extracts from isolates of different geographical origin were used for molecular studies: four of I. vespertilionis, four of I. ariadnae, and two of I. simplex
[2]. From these samples it was attempted to amplify fragments of the $16 \mathrm{~S}$ and $12 \mathrm{~S}$ rDNA genes, as well as the subolesin gene as reported [7-9]. PCR products were resin purified (Wizard, Promega) and cloned into the pGEM-T vector (Promega, Madison, WI, USA) for sequencing both strands (Secugen S.L., Madrid, Spain). Obtained sequences were submitted to the GenBank (accession numbers: KM455956-65 for $12 \mathrm{~S}$ genotypes A-J, respectively; KM455966-70 for 16 S genotypes A, B, E, F, I, respectively, and KM455971 for subolesin gene). Phylogenetic analyses were conducted according to the Tamura-Nei model [10] and Maximum Composite Likelihood method by using MEGA version 5.2 [11].

\section{Ethical approval}

Authorization for bat capture was provided by the National Inspectorate for Environment [2].

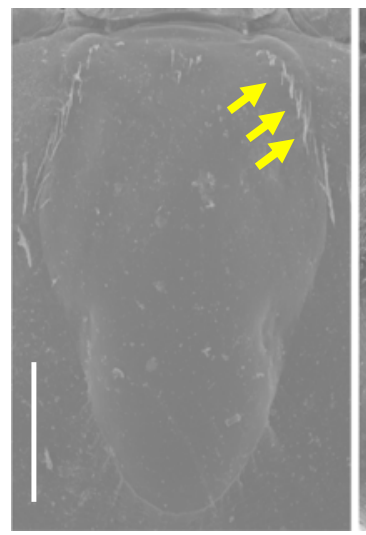

Ixodes vespertilionis

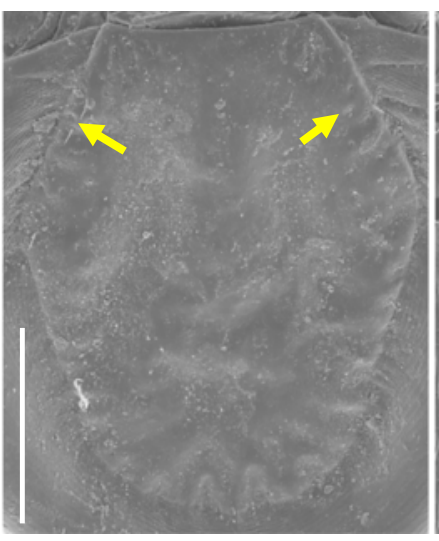

Ixodes ariadnae

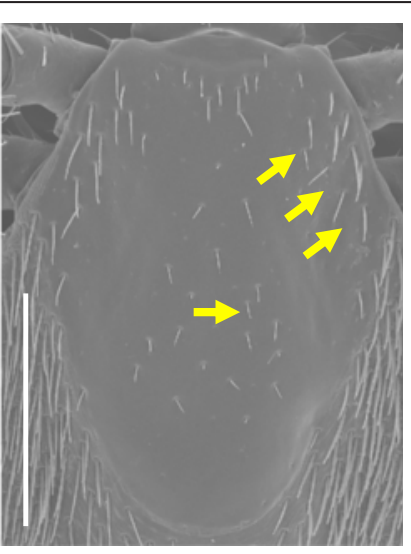

Ixodes simplex

Figure 2 Dorsal view of the scutum of the three bat tick species. Arrows indicate hair-covering (bars: $500 \mu \mathrm{m})$. 


\section{Results and discussion}

\section{Scanning electron microscopy of females}

Concerning the gnathosoma of the three bat tick species, the palps of $I$. vespertilionis are the longest and narrowest (Figure 1). On the other hand, I. ariadnae and I. simplex have short, broad palps; in the latter species with indistinct separation of segments II-III and only short hair (Figure 1). The teeth on the hypostome of I. vespertilionis point backward. This species has sharp posterolateral flange on the basis capituli, whereas in I. ariadnae it is less produced. The two areae porosae of $I$. vespertilionis and I. ariadnae are circumscribed, with densely situated, small pits; unlike those of I. simplex with scattered pits (Figure 1).

On the idiosoma the scutum is the narrowest in $I$. vespertilionis, and broadest (especially posteriorly) in $I$. ariadnae (Figure 2); in the latter species (as contrasted to the other two) with only scarce hair-covering anterolaterally. In case of $I$. simplex middle scutal hairs are also present (Figure 2). Pinnate, hair-like setae were only noted on $I$. simplex (Figure 3 ). The coxae of $I$. ariadnae are posteroexternally convex (Figure 4), and

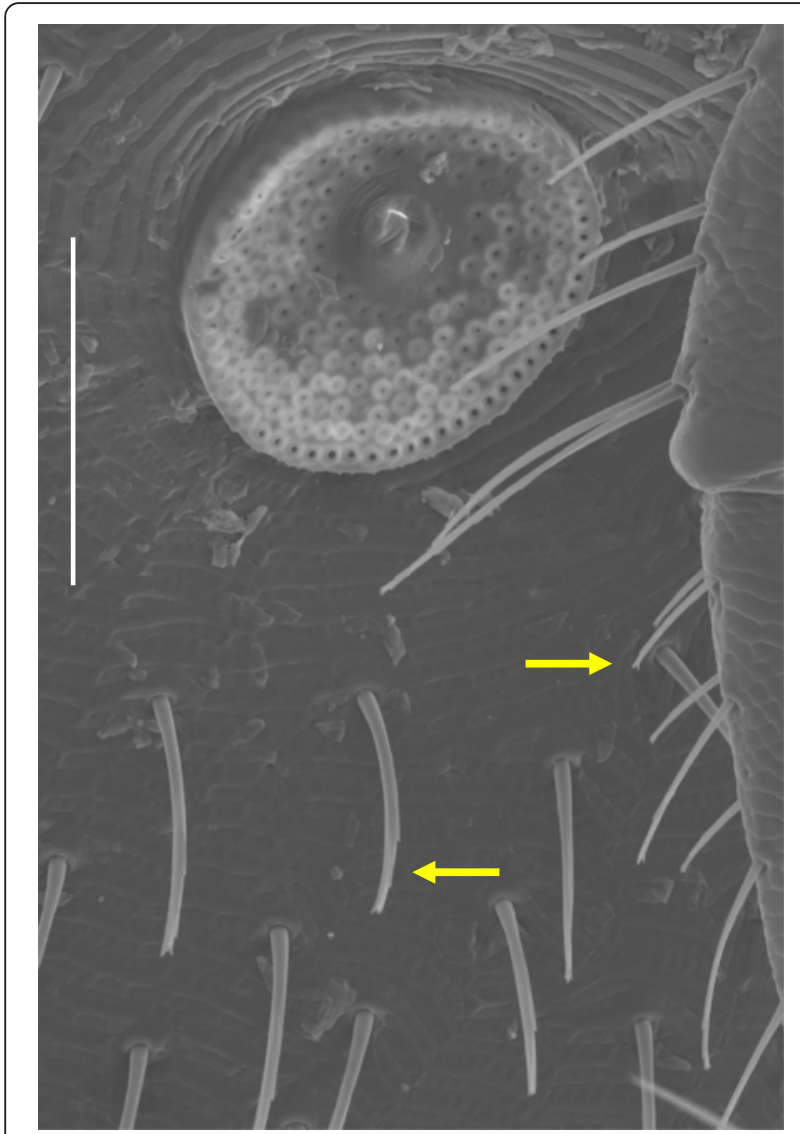

Figure 3 Pinnate, hair-like setae of Ixodes simplex around the peritreme (bar: $200 \mu \mathrm{m}$ ).
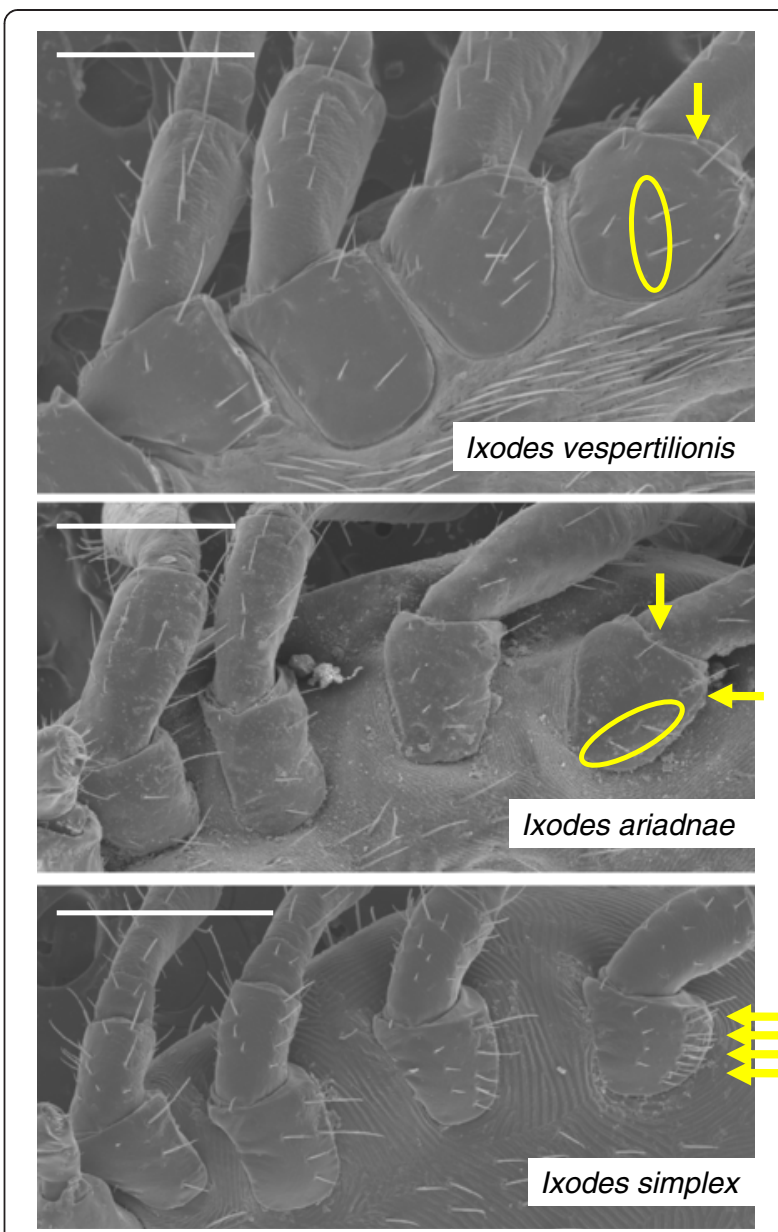

Figure 4 Ventrolateral aspect of the idiosoma of the three bat tick species. Characteristic arrangements of setae on coxae IV are encircled or indicated by arrows (bars: $500 \mu \mathrm{m}$ ).

the arrangement of coxal setae is different in all the three species (Figure 4). Consistently with the long legs of both I. vespertilionis and I. ariadnae, their Haller's organ is also elongated (Figure 5). The arrangement of anterior pit sensillae is linear in I. vespertilionis, whereas focal in two groups in the case of I. ariadnae and in one group in the case of I. simplex (Figure 5).

\section{Molecular analyses}

Recently it has been suggested that for molecular identification of tick species sequencing of the COI gene should be the first method of choice, and analysis of $12 \mathrm{~S}$ and $16 \mathrm{~S}$ rDNA genes can be performed as complementary tests $[5,7,8]$. Prior to this study there was only one $12 \mathrm{~S}$ (and no 16S) sequence of $I$. vespertilionis in GenBank (U95909), and for I. simplex only other genes have been published [12,13]. Therefore sequences obtained in the present study compensate for this lack 


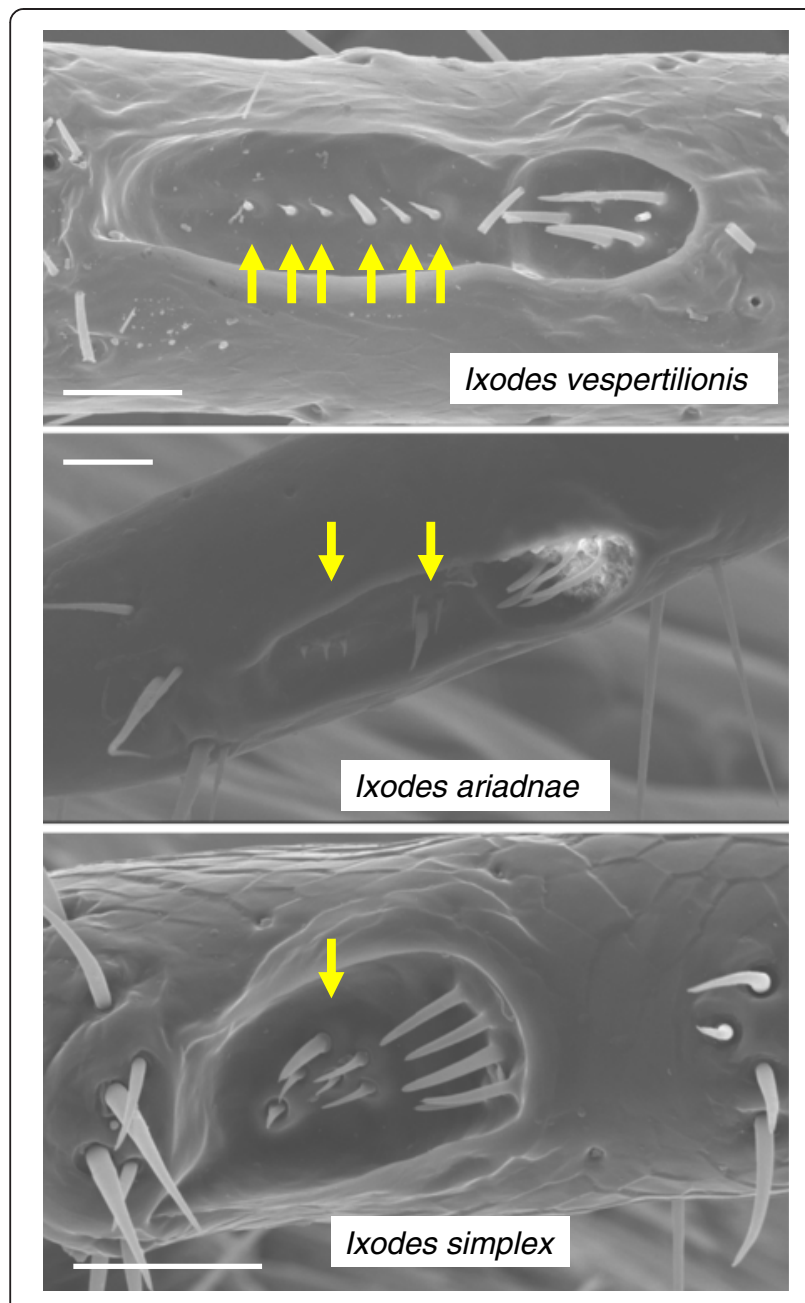

Figure 5 Haller's organ of the three bat tick species. Arrows indicate arrangement of anterior pit sensillae (bars: $50 \mu \mathrm{m}$ ).

of information on genetic markers in case of bat tick species.

Because it is more likely that DNA samples of different geographical origin will show sequence divergence, as demonstrated for both the COI [2] and 12S/16S rDNA genes of ticks [14], tick specimens that were used for molecular genetic comparison in this study were collected at different locations (Figure 6).

Molecular analyses revealed $90-95 \%$ sequence homology in the 12S and 16S rDNA genes of bat tick species (Figure 6). In particular, according to the $12 \mathrm{~S} \mathrm{rDNA}$ gene, the difference between $I$. ariadnae and $I$. vespertilionis is of similar magnitude to that between I. ariadnae and I. simplex (26 vs. 27 nucleotide differences: 94\% vs. 93\% sequence homology, respectively: Figure 6). However, in the $16 \mathrm{~S}$ rDNA gene of its isolates, I. ariadnae appears to be more closely related to I. vespertilionis, than to I. simplex (25 vs. 37 nucleotide differences: 95\% vs. $92 \%$ sequence homology, respectively: Figure 6). In

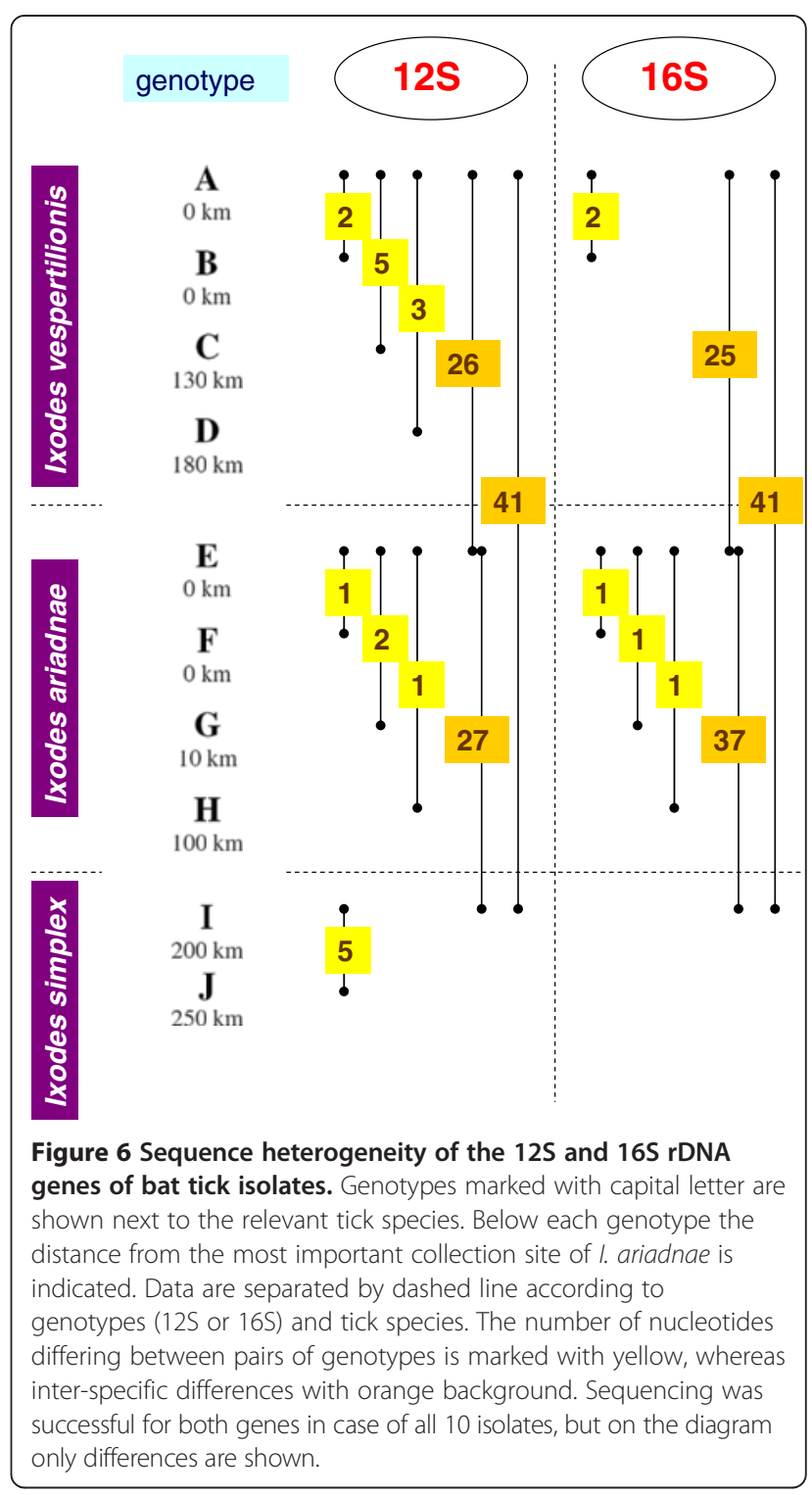

their $12 \mathrm{~S}$ and $16 \mathrm{~S}$ genes I. vespertilionis and I. simplex differed with 41 nucleotides (90\% and 91\% homology, respectively). With bootstrap analyses, isolates/genotypes of the same bat tick species always clustered together, but separately from isolates of other bat tick species. Based on its $12 \mathrm{~S}$ rDNA sequences $I$. ariadnae clustered closest to I. simplex (Figure 7), whereas according to the $16 \mathrm{~S}$ rDNA gene it neighbored I. vespertilionis (Figure 8).

Concerning differences between genotypes of the same bat tick species, I. ariadnae had the lowest sequence heterogeneity in its $12 \mathrm{~S}$ gene (with up to two nucleotide differences), as contrasted to the other two bat tick species (with up to five nucleotide differences) (Figure 6). In line with this, the COI sequences were also highly conserved between isolates of $I$. ariadnae 


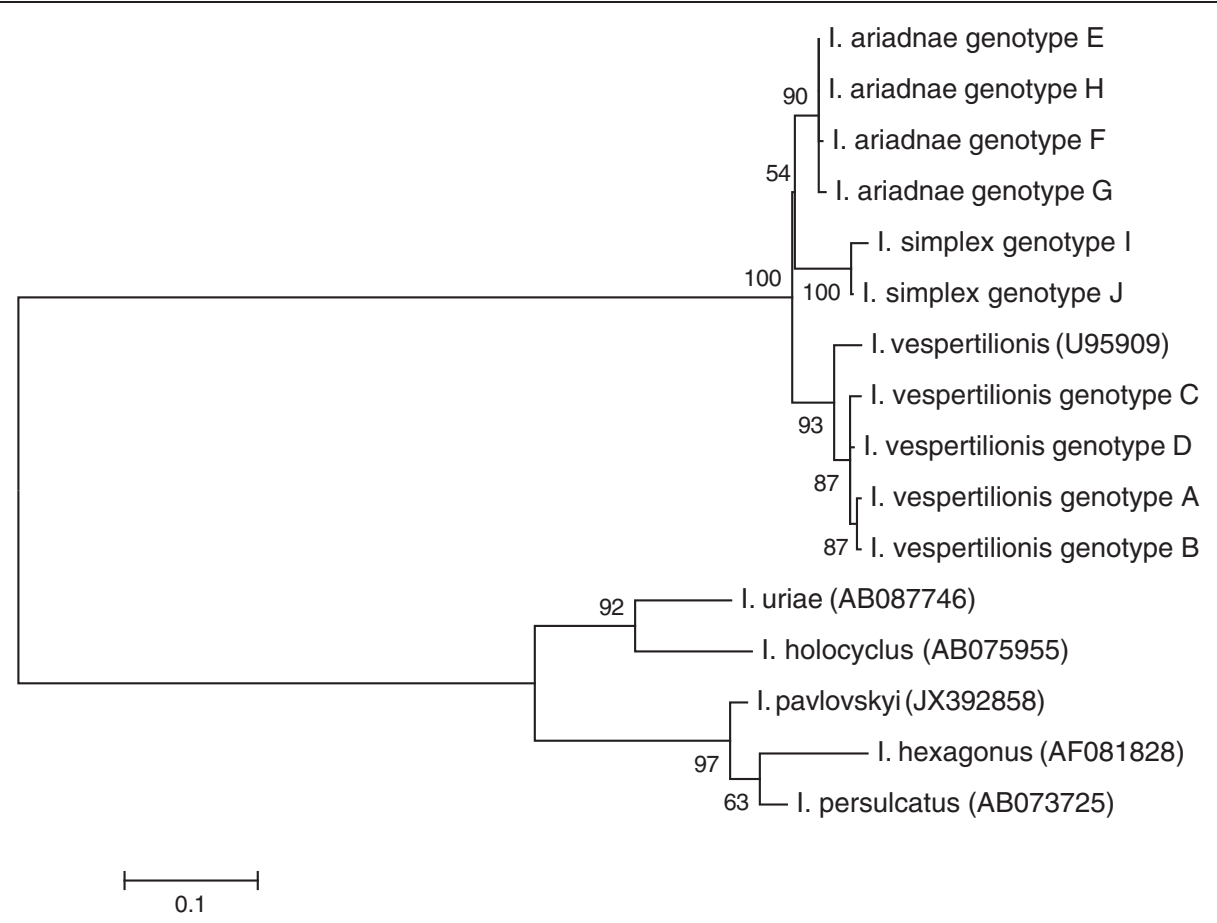

Figure 7 Phylogenetic comparison of 12S rDNA sequences of bat tick genotypes identified in the present study and related sequences from the GenBank. Branch lengths correlate to the number of substitutions inferred according to the scale shown.

[2]. The $12 \mathrm{~S}$ sequences of geographically distant specimens were always different, unlike those of the $16 \mathrm{~S}$ rDNA gene (Figure 6).

The third target of molecular analyses in this study was the subolesin gene. It has an evolutionarily conserved function/sequence and plays a role (among the others) in immunity, development and reproduction of ixodid ticks [9]. Sequencing of this gene was only successful from I. ariadnae (KM455971). The subolesin gene of I. ariadnae clustered the closest to (and had the highest, 95\% sequence homology with) that of $I$. hexagonus (Figure 9), whereas it had only 91\% sequence homology with that of I. ricinus. In comparison with the latter species, the subolesin gene of I. ariadnae contained a $10 \mathrm{bp}$ long and several smaller inserts. Thus, the translated protein had 86 to $88 \%$ similarity (and 16 or 7 amino acids longer strand) in comparison with that of $I$. hexagonus and $I$. ricinus, respectively.

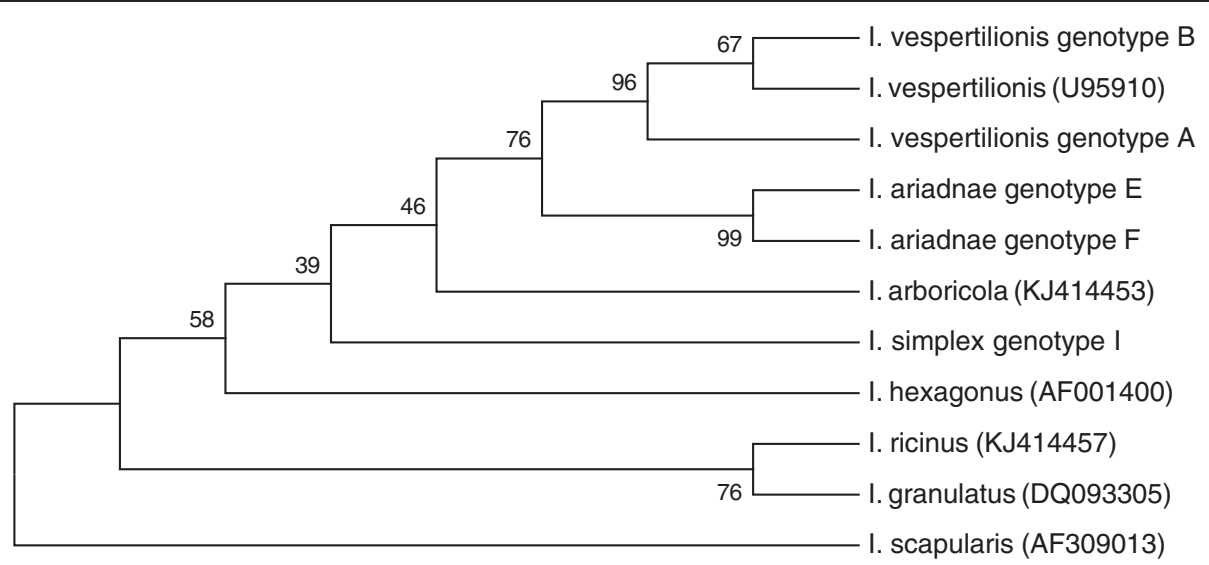

Figure 8 Phylogenetic comparison of 16S rDNA sequences of bat tick genotypes identified in the present study and related sequences from the GenBank. 


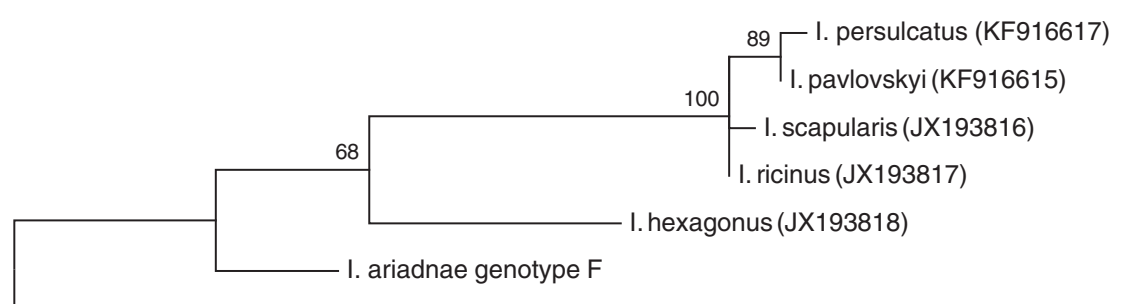

Dermacentor silvarum (JX856138)

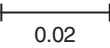

Figure 9 Phylogenetic comparison of the subolesin sequence of Ixodes ariadnae from the present study with related sequences from the GenBank. Branch lengths correlate to the number of substitutions inferred according to the scale shown.

These results also imply, that among all the hard tick species for which the subolesin gene and translated protein was reported so far (in [15]: 10 species of six genera were included), I. ariadnae has the longest known subolesin gene/protein (with 191 amino acids). Taking into account, that according to phylogenetical analyses subolesin sequences may have evolved from longer sequences in Ixodes spp. to shorter ones in other tick genera [15], it is possible that $I$. ariadnae is an ancient tick species. The importance of the latter finding, i.e. a new type of subolesin (protective) gene is further increased by the fact, that this gene is regarded as one of the most likely candidates among the targets of vaccines to control tickinfestations $[9,15]$.

\section{Conclusions}

These results support the taxonomic status of $I$. ariadnae as a separate species, and illustrate the morphological and phylogenetic differences between the three known European bat tick species. According to its subolesin gene I. ariadnae may have a long evolutionary history.

\section{Competing interests}

The authors declare that they have no competing interests.

\section{Authors' contributions}

SH organized the study, processed the samples, extracted the DNA and wrote the manuscript. JK made the electron microscopic pictures and performed phylogenetic analysis. AEP initiated the study and supervised morphological comparisons. ST significantly contributed to the sample collection. IGFM performed molecular analysis and JF arranged, designed and supervised the molecular studies. All authors read and approved the manuscript.

\section{Acknowledgements}

The survey was organized in the framework of the EurNegVec COST Action TD1303. Contribution of ST was supported by a grant from the Ministry of Education, Science and Technological Development of the Republic of Serbia (Project No. 173006). The authors also thank Jelena Burazerovic for collecting I. simplex.

\section{Author details}

${ }^{1}$ Department of Parasitology and Zoology, Faculty of Veterinary Science, Szent István University, Budapest, Hungary. ${ }^{2}$ Plant Protection Institute, Centre for Agricultural Research, Hungarian Academy of Sciences, Budapest, Hungary. ${ }^{3}$ Department of Zoology and Animal Ecology, Szent István University, Gödöllö, Hungary. ${ }^{4}$ Department of Animal Pathology, University of Zaragoza, Zaragoza, Spain. ${ }^{5}$ SaBio. Instituto de Investigación en Recursos Cinegéticos IREC, CSIC-UCLM-JCCM, Ciudad Real, Spain. 'Department for Microbiology and Parasitology, Laboratory for Medical Entomology, Institute for Medical Research, University of Belgrade, Belgrade, Serbia. ${ }^{7}$ Department of Veterinary Pathobiology, Center for Veterinary Health Sciences, Oklahoma State University, Stillwater, USA.

Received: 17 September 2014 Accepted: 16 January 2015

Published online: 24 January 2015

\section{References}

1. Arthur DR. The Ixodes ticks of Chiroptera (Ixodoidea, Ixodidae). J Parasitol. 1956:42:180-96.

2. Hornok S, Kontschán J, Kováts D, Kovács R, Angyal D, Görföl T, et al. Bat ticks revisited: Ixodes ariadnae sp. nov. and allopatric genotypes of I. vespertilionis in caves of Hungary. Parasit Vectors. 2014;7:202.

3. Piksa K, Nowak-Chmura M, Siuda K. First case of human infestation by the tick Ixodes vespertilionis (Acari: Ixodidae). Int J Acarol. 2013;38:1-2.

4. Hornok S, Kovács R, Meli ML, Kontschán J, Gönczi E, Gyuranecz M, et al. First detection of bartonellae in a broad range of bat ectoparasites. Vet Microbiol. 2012;159:541-3.

5. LV J, Wu S, Zhang Y, Chen Y, Feng C, Yuan X, et al. Assessment of four DNA fragments (COI, 16S rDNA, ITS2, 12S rDNA) for species identification of the Ixodida (Acari: Ixodida). Parasit Vectors. 2014;7:93.

6. Hornok S, Kováts D, Csörgő T, Meli ML, Gönczi E, Hadnagy Z, et al. Birds as potential reservoirs of tick-borne pathogens: first evidence of bacteraemia with Rickettsia helvetica. Parasit Vectors. 2014;7:128.

7. Black WC, Piesman J. Phylogeny of hard and soft-tick taxa (Acari: Ixodida) based on mitochondrial 16 s rDNA sequences. Proc Natl Acad Sci U S A. 1994;91:10034-8.

8. Norris DE, Klompen JSH, Black WC. Comparison of the mitochondrial 125 and 165 ribosomal DNA genes in resolving phylogenetic relationships among hard ticks (Acari: Ixodidae). Ann Entomol Soc Am. 1999;92:117-29.

9. de la Fuente J, Maritz-Olivier C, Naranjo V, Ayoubi P, Nijhof AM, Almazán C, et al. Evidence of the role of tick subolesin in gene expression. BMC Genomics. 2008;9:372.

10. Tamura K, Nei M. Estimation of the number of nucleotide substitutions in the control region of mitochondrial DNA in humans and chimpanzees. Mol Biol Evol. 1993;10:512-26.

11. Tamura K, Peterson D, Peterson N, Stecher G, Nei M, Kumar S. MEGA5: molecular evolutionary genetics analysis using maximum likelihood, evolutionary distance, and maximum parsimony methods. Mol Biol Evol. 2011;28:2731-9.

12. Dobson SJ, Barker SC. Phylogeny of the hard ticks (Ixodidae) inferred from $18 \mathrm{~S}$ rRNA indicates that the genus Aponomma is paraphyletic. Mol Phylogenet Evol. 1999;11:288-95. 
13. Shao R, Barker SC, Mitani H, Aoki Y, Fukunaga M. Evolution of duplicate control regions in the mitochondrial genomes of metazoa: a case study with Australasian Ixodes ticks. Mol Biol Evol. 2005;22:620-9.

14. Mangold AJ, Bargues MD, Mas-Coma S. Mitochondrial $16 \mathrm{~S}$ rDNA sequences and phylogenetic relationships of species of Rhipicephalus and other tick genera among Metastriata (Acari: Ixodidae). Parasitol Res. 1998;84:478-84.

15. de la Fuente J, Almazán C, Blas-Machado U, Naranjo V, Mangold AJ, Blouin $\mathrm{EF}$, et al. The tick protective antigen, $4 \mathrm{D} 8$, is a conserved protein involved in modulation of tick blood ingestion and reproduction. Vaccine. 2006;24:4082-95.

\section{Submit your next manuscript to BioMed Central} and take full advantage of:

- Convenient online submission

- Thorough peer review

- No space constraints or color figure charges

- Immediate publication on acceptance

- Inclusion in PubMed, CAS, Scopus and Google Scholar

- Research which is freely available for redistribution 